\title{
Mikrozonasi Seismik Di Wilayah Ancaman Sesar Lembang Antara Seksi Cihideung Dan Gunung Batu Berdasarkan Pengukuran Mikrotremor
}

\author{
Reza Fahrurijal ${ }^{1 *}$, Adrin Tohari $^{2}$, Imamal Muttaqien ${ }^{1}$ \\ ${ }^{1}$ Program Studi Fisika, Fakultas Sains dan Teknologi, Universitas Islam Negeri Sunan Gunung Djati \\ Bandung, Jl. A.H. Nasution, Cibiru Bandung 40614 \\ ${ }^{2}$ Kelompok Penelitian Gerakan Tanah, Pusat Penelitian Geoteknologi, LIPI, Jl. Sangkuriang, Cisitu, \\ Bandung 40135
}

\begin{abstract}
ABSTRAK Sesar Lembang merupakan salah satu sesar aktif yang mengancam wilayah Jawa Barat. Upaya pengurangan risiko dari ancaman sesar ini memerlukan pengetahuan mengenai tingkat kerentanan seismik di wilayah yang berada di zona sesar. Makalah ini menyajikan hasil analisis rasio spektral H/V dari data pengukuran mikrotremor di sepanjang zona Sesar Lembang, antara Seksi Cihideung dan Gunung Batu, untuk menghasilkan mikrozonasi kerentanan seismik di wilayah Kecamatan Lembang dan Parongpong. Hasil analisis menunjukkan bahwa wilayah Kecamatan Lembang dan Parongpong yang tersusun oleh lapisan endapan danau dan pasir tufan, umumnya dicirikan oleh nilai frekuensi dominan yang rendah dan faktor amplifikasi sedang hingga tinggi. Berdasarkan indeks kerentanan seismik, kedua kecamatan ini secara umum dapat diklasifikasikan sebagai daerah dengan kerentanan seismik yang tinggi. Akan tetapi, daerah yang terbentuk dari lapisan breksi tua di
\end{abstract}

*Penulis korespondensi.

Email: rezafahrurijal@gmail.com

Kecamatan Lembang memiliki kerentanan seismik yang rendah, sedangkan daerah-daerah di wilayah Kecamatan Parongpong di sepanjang Seksi Cihideung yang tersusun oleh lapisan pasir tufan merupakan daerah dengan kerentanan seismik sedang. Dengan demikian, kerentanan seismik wilayah ancaman Sesar Lembang sangat spesifik di setiap daerah dan dipengaruhi oleh jenis satuan litologi.

Kata Kunci: frekuensi dominan, faktor amplifikasi, indeks kerentanan seismik, mikrotremor, rasio spektral, Sesar Lembang.

ABSTRACT Seismic microzonation of Lembang Fault hazard area along Cihideung and Gunung Batu sections using microtremor measurements. Lembang Fault is amongst the active faults that pose a significant threat to the West Java region. Mitigation efforts in reducing seismic risks associated with this fault require knowledge of seismic vulnerability in the area along the fault zone. This paper presents the results of horizontal to vertical $(H / V)$ spectral ratio analysis of microtremor data across the Lembang Fault zone, measured along the Cihideung and Gunung Batu Sections, to establish a seismic vulnerability microzonation of Lembang and Parongpong Subdistricts. The study shows that the Lembang and Parongpong Sub-district areas that composed of lake sediments and tuffaceous sand units are generally characterized by low dominant frequencies and medium to high amplification factors. According to their seismic vulnerability indices, in general, these two sub-districts can be classified as areas with high seismic vulnerability. However, the areas covered by the old breccia unit in the Lembang Sub-district have low seismic susceptibility, while the areas covered by the 
tuffaceous sand unit along the Cihideung Section in Parongpong Subdistrict have medium seismic vulnerability. Thus, this study indicates that the seismic vulnerabilities of Lembang Fault hazard area are considerably site-specific and influenced by the lithology.

Keywords: dominant frequency, amplification factor, seismic vulnerability index, microtremor, spectral ratio, Lembang Fault.

\section{PENDAHULUAN}

Secara tektonik, wilayah Indonesia merupakan titik pertemuan antara tiga lempeng besar, yaitu lempeng Indo-Australia, lempeng Eurasia, dan lempeng Pasifik (Harijono, 2010). Konsekuensinya, dinamika lempeng tersebut memicu terjadinya pergerakan sesar yang berada di daratan, salah satunya Sesar Lembang yang berada di Jawa Barat.

Jawa Barat merupakan provinsi yang memiliki penduduk terbanyak di Indonesia dengan populasi penduduk diproyeksikan mencapai 48.683 .860 jiwa di tahun 2018 (BPS Propinsi Jawa Barat, 2019). Disamping itu, Jawa Barat memiliki banyak lokasi yang berpotensi untuk dijadikan lokasi wisata, salah satunya daerah Lembang di Kabupaten Bandung Barat. Kawasan Lembang ini merupakan daerah yang berpotensi sangat tinggi sebagai pusat pertanian, peternakan, dan pariwisata. Tetapi dilihat dari kondisi geologinya, kawasan Lembang merupakan daerah yang rawan terhadap aktivitas gempabumi karena diapit oleh Gunung Tangkuban Perahu di sebelah utara dan Sesar Lembang yang masih aktif di sebelah selatan.

Sesar Lembang melintang dari timur ke barat sepanjang $29 \mathrm{~km}$ dan terbagi menjadi 6 seksi, yaitu Seksi Cimeta, Cipogor, Cihideung, Gunung Batu, Cikapundung dan Batu Lonceng (Daryono, 2016; Daryono et al., 2019). Sesar ini merupakan jenis sesar normal dengan bagian utaranya relatif lebih turun sedalam 450 meter, terutama di bagian timur sesar (Brahmantyo, 2011). Berdasarkan penelitian yang dilakukan oleh Kertapati (2006), sesar ini merupakan sesar yang masih aktif bergerak dan merupakan sumber gempabumi. Pernyataan tersebut didukung oleh data pergeseran Sesar Lembang dengan laju rata-rata sekitar 0,3 sampai $1,4 \mathrm{~cm} /$ tahun dari hasil pemantauan dengan menggunakan metode GPS (Abidin et al., 2009). Mempertimbangkan potensi pergerakan Sesar
Lembang yang bisa menimbulkan gempabumi besar berskala 6,5 hingga 7,0 Mw (Daryono, 2016; Daryono et al., 2019), maka perlu dilakukan pemetaan sifat dinamika lapisan tanah dan tingkat kerentanan seismik di wilayah bahaya Sesar Lembang sebagai acuan dalam melakukan upaya pengurangan risiko gempabumi.

Metode pengukuran mikrotremor merupakan salah satu metode geofisika yang dapat menyediakan data frekuensi resonansi utama dan faktor amplifikasi untuk lapisan tanah berdasarkan pada perbedaan impedansi yang kuat antara lapisan tanah dan batuan dasar (Ansal, 2004). Metode ini menggunakan perhitungan Horizontal to Vertical Spectral Ratio (HVSR) (Nakamura, 1989). Metode mikrotremor telah digunakan oleh peneliti terdahulu untuk mengevaluasi efek tapak dan menghasilkan peta mikrozonasi seismik (Fallahi et al., 2003; Tuladhar et al., 2004; Davenport dan Stephenson, 2005; BonnefoyClaudet et al., 2008; Gosar, 2009; Claprood dan Asten, 2008; Kiyono et al., 2010; Eskisar et al., 2013). Tohari dan Wardana (2018) menggunakan metode mikrotremor untuk memetakan kerentanan seismik di Kota Padang dengan memperhatikan tingkat kerusakan bangunan akibat gempabumi 30 September 2009. Hasil penelitian mengindikasikan bahwa bangunan yang rusak berat hingga runtuh umumnya berada di wilayah dengan faktor amplifikasi lebih besar dari 12.

Makalah ini menyajikan hasil analisis data pengukuran mikrotremor di zona Sesar Lembang antara Seksi Cihideung dan Gunung Batu dengan menggunakan metode HVSR (Horizontal to Vertical Spectral Ratio) untuk menghasilkan mikrozonasi kerentanan seismik di wilayah Kecamatan Lembang dan Kecamatan Parongpong. Adapun sasaran dari analisis ini untuk (1) mengevaluasi sebaran nilai frekuensi dominan dan faktor amplifikasi tanah, dan (2) menyusun peta mikrozonasi seismik berdasarkan indeks kerentanan seismik.

\section{KONDISI GEOLOGI}

Dataran tinggi Bandung Utara dipisahkan dari Cekungan Lembang oleh Sesar Lembang yang ditandai dengan serangkaian lereng-lereng linier mengarah timur-barat. Daerah Cekungan Lembang dipenuhi dengan endapan aluvial muda dan produk vulkanik berumur Kuarter di 


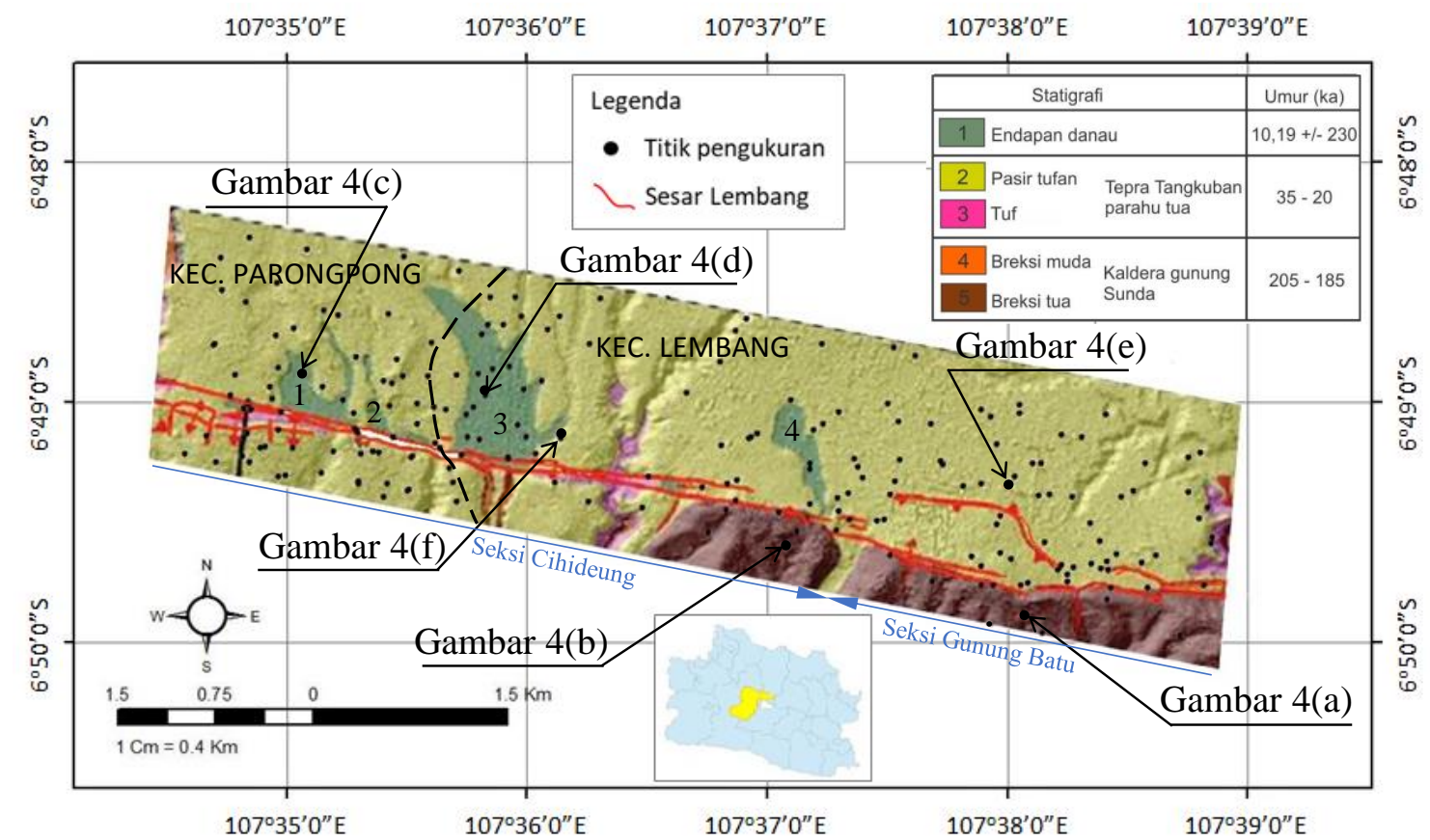

Gambar 1. Peta geologi daerah sekitar zona Sesar Lembang (modifikasi dari Daryono et al, 2019). Lokasi cekungan: (1) Ciwaruga, (2) Cibereum, (3) Cihideung dan (4) Situ Umar.

Garis hitam putus-putus adalah batas wilayah.

sepanjang bagian selatan sisi gunung berapi Tangkuban Perahu (van Bemmelen, 1949; Tjia, 1968; Silitonga, 1973; Marjiyono et al., 2008). Sementara itu, bagian punggungan sesar terdiri dari berbagai jenis batuan vulkanik Kuarter (Silitonga, 1973).

Hasil pemetaan geologi yang dilakukan oleh Daryono (2016) di wilayah Sesar Lembang, menggunakan metode LIDAR dan IFSAR, membagi litologi di wilayah sesar tersebut menjadi lima unit litologi sebagai berikut (lihat Gambar 1):

1. Endapan danau: geomorfologi satuan litologi ini ditandai dengan topografi datar halus yang mengisi cekungan terisolasi sepanjang sisi utara Sesar Lembang. Di lokasi penelitian, endapan danau ini ditemukan di empat lokasi yaitu di Cekungan Ciwaruga, Cibeureum, Cihideung, dan Situ Umar sebagaimana ditunjukkan pada Gambar 1.

2. Pasir tufan: satuan litologi ini didominasi oleh pasir tufan kasar yang terdiri atas fragmen batuan beku dan tuf dengan ukuran $0,5-1 \mathrm{~cm}$ Ketebalan satuan litologi ini diperkirakan sekitar $45 \mathrm{~m}$. Gemorfologi satuan litologi ini ditandai dengan topografi bergelombang- halus yang telah tertoreh oleh aliran sungai utama.

3. Tuf: satuan litologi ini terdiri dari lapisan tuf putih dan lapisan kaya batuapung dengan fragmen batuapung berukuran $0,5-20 \mathrm{~cm}$ yang hanya dijumpai di lembah-lembah sungai yang dalam, seperti di Sungai Cihideung dan Cigulung di lokasi penelitian. Satuan litologi ini mempunyai ketebalan total sekitar $40 \mathrm{~m}$. Pembentukan batuan ini diduga berasosiasi dengan pendangkalan permukaan air Danau Bandung pada 25-20 ka (Dam et al., 1996) dan letusan utama Gunung Api Sunda dan Tangkuban Perahu pada periode 35-20 ka (Dam, 1994; Dam et al., 1996; Kartadinata et al., 2002).

4. Breksi (vulkanik) muda: satuan litologi ini dicirikan oleh kemas terbuka, warna coklat kemerahan, keras, matriks berupa pasir kasar dan tuf dengan fragmen berupa batuan andesitik berbentuk menyudut berukuran 10 $100 \mathrm{~cm}$. Satuan litologi ini dapat ditemukan di bagian lembah Sungai Cihideung di lokasi penelitian.

5. Breksi tua: satuan litologi ini terdiri dari breksi vulkanik yang kompak, matriks berupa pasir 


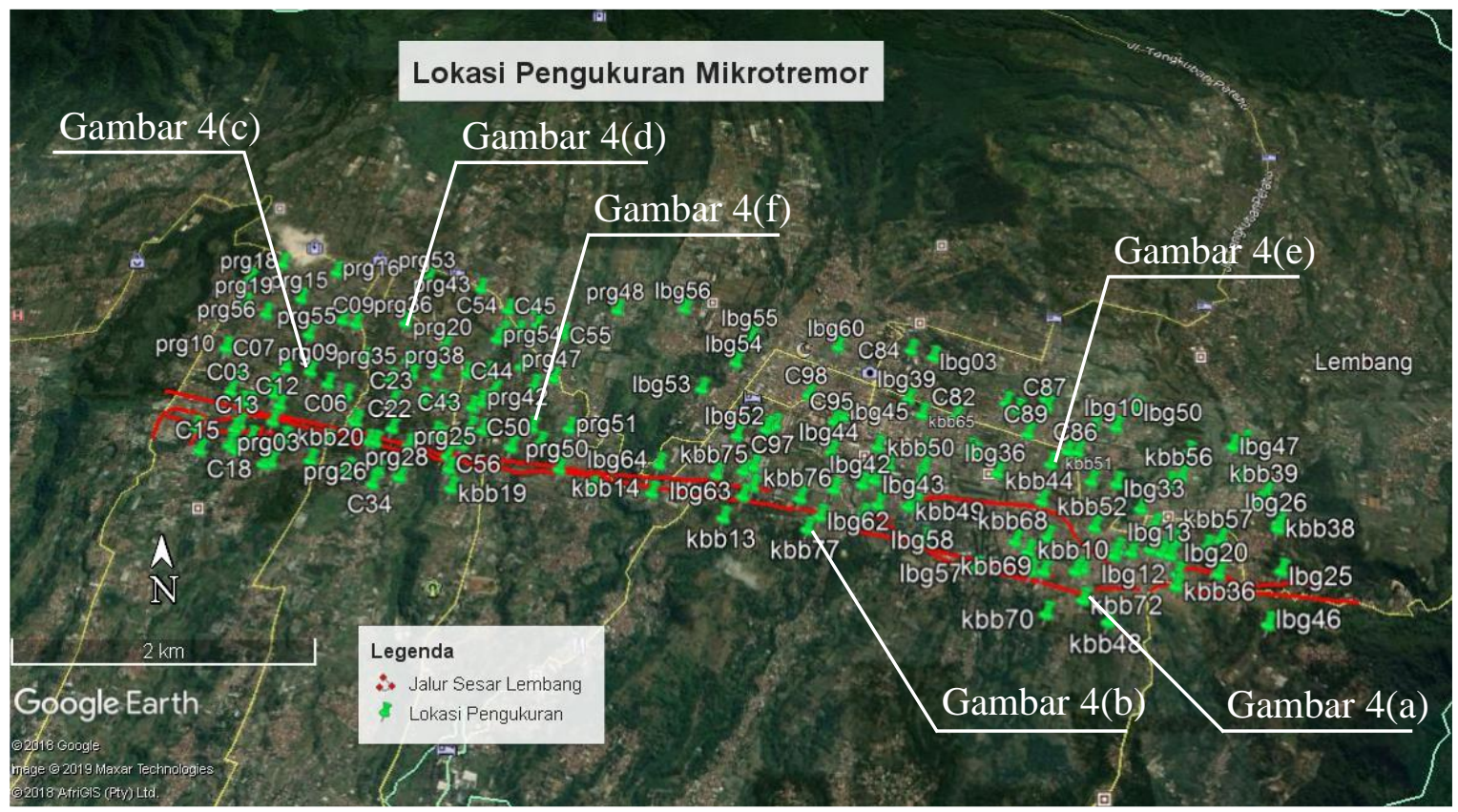

Gambar 2. Lokasi pengambilan data mikrotremor di wilayah Kecamatan Lembang dan Kecamatan Parongpong. Garis warna merah menunjukkan lokasi zona Sesar Lembang.

dan tuf dan fragmen berupa batuan beku menyudut dengan kemas terbuka. Geomorfologi satuan litologi ditunjukkan oleh topografi perbukitan tua berelief tinggi dengan aliran air sungai yang dalam.

\section{METODE}

\section{Pengambilan data mikrotremor}

Pengukuran data mikrotremor dilakukan pada 180 titik yang tersebar di sepanjang zona Sesar Lembang di wilayah Kecamatan Lembang dan Kecamatan Parongpong, Kabupaten Bandung Barat dengan mempertimbangkan jenis satuan litologi (Gambar 2). Namun, pengambilan data mikrotremor tidak dapat dilakukan pada satuan litologi tuf dan breksi vulkanik muda karena lokasi-lokasi satuan litologi tersebut berada di lereng yang terjal dan dasar lembah yang dalam.

Peralatan yang digunakan dalam pengukuran mikrotremor adalah sebagai berikut (Gambar 3):

- Sensor velocity-meter tipe GEODAQS1$2 S 3 D C F$ yang berfungsi untuk merekam getaran ambient yang menjalar dari dalam lapisan tanah. Sensor kecepatan ini mengukur 3 komponen getaran, yaitu 2 komponen horizontal (utara-selatan dan barat-timur) dan 1 komponen vertikal (atas-bawah).

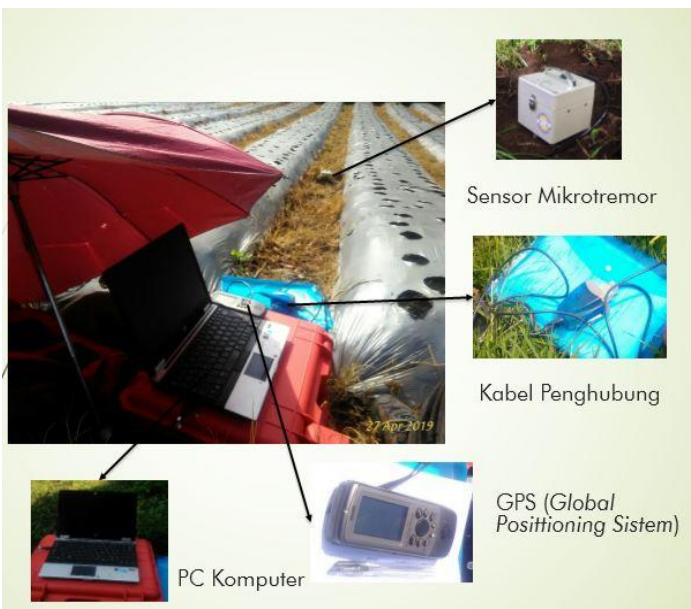

Gambar 3. Peralatan survei mikrotremor.

- Kabel sebagai penghubung antara velocitymeter dengan komputer.

- Personal computer sebagai media penyimpan data hasil rekaman gelombang.

- GPS (Global Positioning System) digunakan untuk menentukan koordinat setiap titik penelitian.

Pengambilan data diawali dengan survei lokasi untuk menentukan lokasi pengukuran. Lokasi yang dipilih adalah yang berada jauh dari jalan raya dan keramaian dengan maksud untuk meminimalisir sumber-sumber getaran 
monokromatik (mesin pabrik, pompa air, mesin generator) dan sumber getaran sementara (langkah kaki, kendaraan lewat). Kemudian alat miktrotremor dikalibrasi untuk memastikan alat tersebut dapat berfungsi sebagaimana mestinya.

Pengukuran mikrotremor dilakukan pada siang hari pada permukaan lapisan tanah asli di setiap lokasi yang sudah disurvei sebelumnya. Pengambilan data di semua titik pengukuran dilakukan selama 660 detik dengan menggunakan frekuensi $100 \mathrm{~Hz}$. Semua waktu pengukuran disinkronasikan dengan menggunakan waktu referensi pada alat global positioning system (GPS) yang terhubung dengan alat mikrotremor.

\section{Pengolahan data mikrotremor}

Hasil pengukuran mikrotremor dengan sensor tiga komponen, yaitu kompenen utara-selatan $(N S)$ dan komponen timur-barat $(E W)$ sebagai sumbu horizontal, dan atas-bawah (UD) sebagai sumbu vertikal, diolah dengan menggunakan software Geonet. Pada software tersebut dilakukan windowing sinyal, yaitu membagi sinyal kedalam beberapa window. Pemilahan ini (windowing) dilakukan untuk memisahkan antara sinyal tremor dengan noise (gangguan seperti langkah kaki, getaran dari kendaraan/mesin dan aktivitas manusia lainnya). Kemudian data dalam domain waktu tersebut diubah menjadi domain frekuensi menggunakan filter Fast Fourier Transform $(F F T)$. Nilai faktor amplifikasi (rasio spektral $H / V)$ dihitung menggunakan persamaan dibawah ini (Nakamura, 1989):

$$
H V S R=\sqrt{\left(X_{N S}\right)^{2}+\left(X_{E W}\right)^{2}} / X_{U D}
$$

dimana HVSR adalah Horizontal to Vertical Spektral Ratio/faktor amplifikasi, $X_{N S}$ adalah spektral fourier untuk arah utara-selatan, $X_{E W}$ adalah spektral fourier untuk arah timur-barat dan $X_{U D}$ adalah spektral fourier untuk arah atas bawah.

Setelah mendapatkan nilai faktor amplifikasi maka dibuat spektral antara nilai faktor amplifikasi dan nilai frekuensi dominan sehingga didapatkan nilai puncak spektral yang menunjukkan impedansi antara lapisan tanah dan batuan dasar.

Dari nilai faktor amplifikasi dan frekuensi dominan dihasilkan nilai indeks kerentanan seismik. Indeks kerentanan seismik adalah indeks yang menggambarkan tingkat kerentanan lapisan tanah permukaan terhadap deformasi saat terjadi gempabumi (Nakamura, 2000). Indeks kerentanan seismik dapat dihitung dengan menggunakan persamaan Nakamura (1997) dibawah ini:

$$
K_{g}=A_{0}^{2} / f_{0}
$$

dimana $K_{g}$ adalah indek kerentanan seismik, $A_{0}$ adalah faktor amplifikasi dan $f_{0}$ adalah frekuensi dominan tanah $(\mathrm{Hz})$.

Hasil pengolahan data pengukuran digunakan untuk pembuatan peta zonasi frekuensi dominan, faktor amplifikasi, dan indek kerentanan seismik dengan menggunakan peranti lunak ArcGIS. Untuk memperlihatkan pengaruh perbedaan ketebalan lapisan tanah di setiap satuan litologi maka nilai $f_{0}$ dibagi menjadi 5 zonasi dengan mempertimbangkan rentang nilai $f_{0}$ di setiap satuan litologi. Klasifikasi faktor amplifikasi merujuk kepada Tohari dan Wardhana (2018), sedangkan klasifikasi indeks kerentanan seismik dibangun berdasarkan variasi nilai $K_{g}$ di setiap satuan litologi.

\section{HASIL DAN PEMBAHASAN}

\section{Karakteristik rasio spektral $H / V$}

Hasil analisis data mikrotremor menunjukkan bahwa spektral $H / V$ lapisan tanah memiliki nilai puncak yang berbeda-beda (Gambar 4). Perbedaan nilai puncak pada kurva spektral dan frekuensi dominan disebabkan oleh faktor variasi kepadatan lapisan tanah dan kedalaman batuan dasar. Jenis satuan litologi yang mempengaruhi tipe kurva spektral $H / V$ dapat dilihat pada Gambar 1.

Gambar 4a dan Gambar 4b menunjukkan ciri spektra $H / V$ pada lapisan breksi vulkanik tua dengan nilai amplifikasi rendah dan frekuensi dominan tanah tinggi yang mengindikasikan lapisan tanah tipis di atas lapisan breksi tersebut. Sementara itu, spektral $H / V$ pada lapisan endapan danau di Cekungan Cihideung ditunjukkan pada Gambar 4c, dicirikan dengan nilai faktor amplifikasi tinggi dan nilai frekuensi dominan sangat rendah. Sedangkan Gambar 4d menyajikan spekral $H / V$ pada lapisan endapan danau yang mengering dengan nilai faktor amplifikasi tinggi dan nilai frekuensi dominan rendah. Dengan demikian, lapisan endapan danau cenderung 


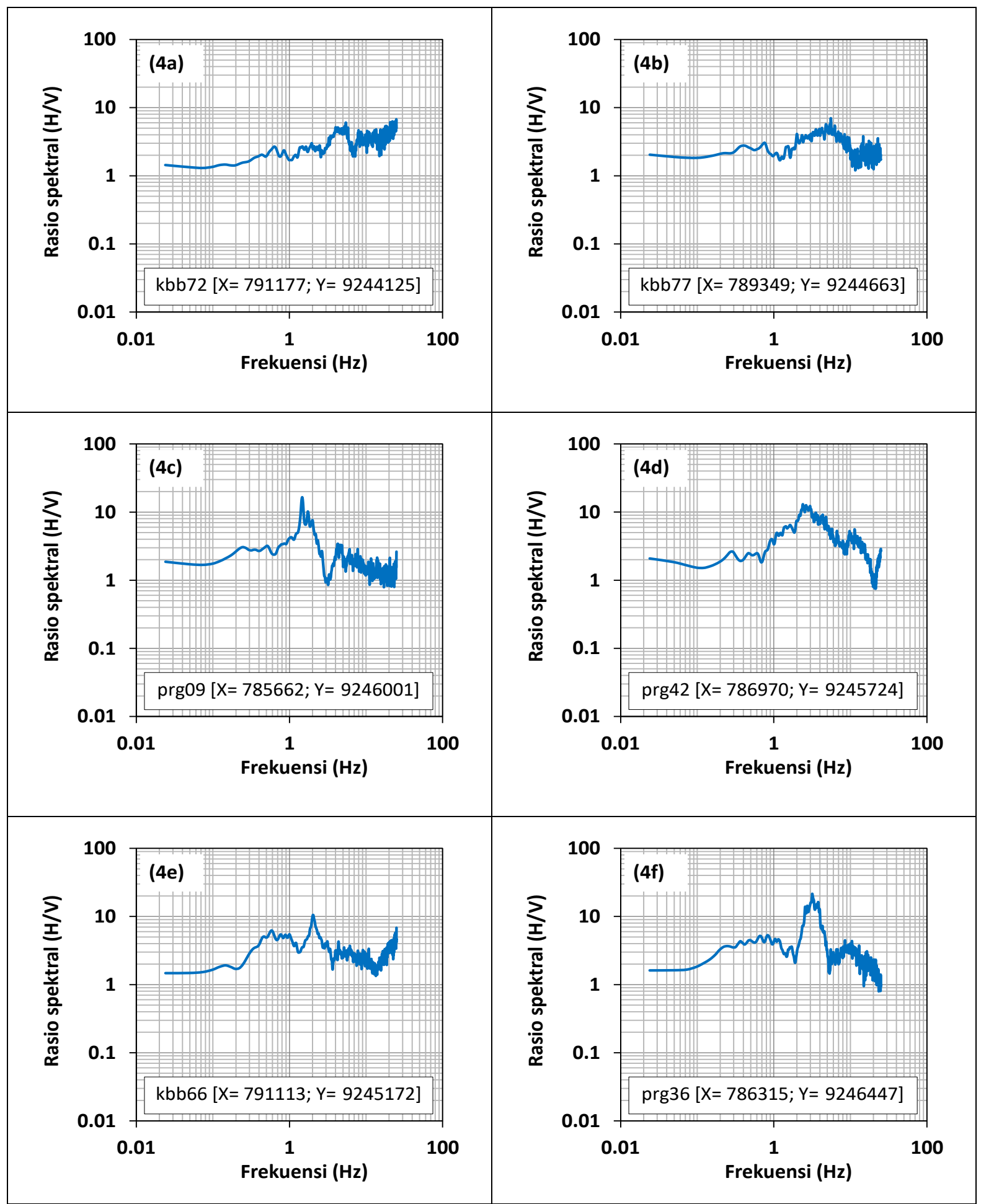

Gambar 4. Rasio spektral H/V berdasarkan jenis litologi di wilayah zona Sesar Lembang: lapisan breksi vulkanik tua ( $4 \mathrm{a}$ dan $4 \mathrm{~b})$, endapan danau ( $4 \mathrm{c}$ dan $4 \mathrm{~d})$, dan lapisan pasir tufan ( $4 \mathrm{e}$ dan 4f).

memiliki ketebalan yang bervariasi sehingga akan menghasilkan efek tapak yang berbeda di setiap wilayah.
Spektral $H / V$ pada lapisan tuf di wilayah Kecamatan Lembang (Gambar 4e) dicirikan oleh nilai faktor amplifikasi tinggi dan nilai frekuensi dominan sangat rendah, sedangkan lapisan pasir 
tufan di wilayah Kecamatan Parongpong mempunyai nilai faktor amplifikasi sangat tinggi dan nilai frekuensi rendah (Gambar 4f). Hal ini mengindikasikan bahwa lapisan pasir tufan di wilayah Kecamatan Lembang lebih tebal dibandingkan dengan lapisan pasir tufan di wilayah Kecamatan Parongpong.

\section{Sebaran nilai frekuensi dominan $\left(f_{0}\right)$}

Zonasi nilai frekuensi dominan lapisan tanah di wilayah zona Sesar Lembang di Kecamatan Lembang dan Parongpong ditunjukkan pada Gambar 5. Nilai frekuensi dominan sangat bervariasi di setiap satuan litologi sebagaimana disajikan dalam Tabel 1. Karena pengukuran mikrotremor tidak dapat dilakukan pada satuan litologi tuf dan breksi vulkanik muda, maka nilai frekuensi dominan untuk kedua satuan litologi tersebut diperoleh dari hasil interpolasi nilai-nilai frekuensi dominan yang tersedia.

Nilai frekuensi sangat rendah $\left(f_{0}<2 \mathrm{~Hz}\right)$ terukur pada wilayah Kecamatan Lembang yang terletak di sebelah utara sesar dan pada sebagian wilayah
Kecamatan Parongpong yang berada di sisi selatan sesar. Berdasarkan peta geologi (Gambar 1), lapisan tanah di kedua wilayah ini didominasi oleh lapisan pasir tufan dan juga endapan danau yang memiliki tingkat kepadatan yang rendah sehingga lapisan tanah tersebut mempunyai kemampuan sangat rendah dalam merambatkan getaran. Saat ini sebagian besar lapisan endapan danau purba di Cekungan Ciwaruga, Cibereum, dan Cihideung telah ditimbun untuk dijadikan lahan perumahan sehingga kawasan tersebut akan memiliki risiko gempabumi yang lebih besar dibandingkan dengan daerah di sekitarnya.

Berdasarkan peta mikrozonasi frekuensi dominan lapisan tanah (Gambar 5), lapisan pasir tufan memiliki nilai frekuensi dominan antara 2 dan 3 $\mathrm{Hz}$ di kedua wilayah ini. Di wilayah Kecamatan Lembang, lapisan pasir tufan dengan frekuensi dominan rendah ini berada tepat di sisi utara Sesar Lembang pada Seksi Gunung Batu. Hal ini berarti bahwa lapisan pasir tufan di lokasi ini lebih tipis dibandingkan dengan lapisan pasir tufan di lokasi yang lebih ke utara dari Sesar Lembang. Dengan demikian, variasi ketebalan lapisan pasir tufan ini

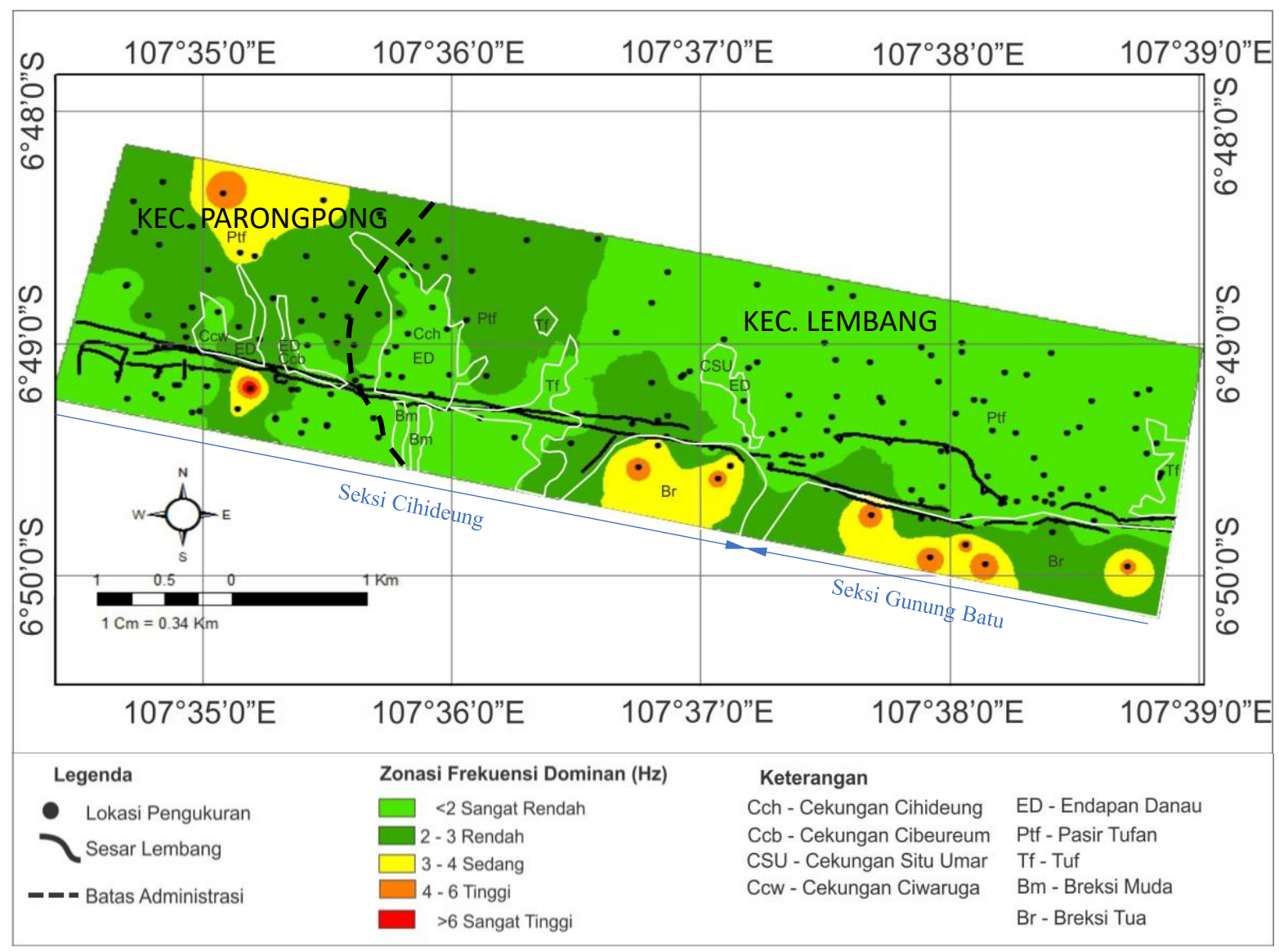

Gambar 5. Peta mikrozonasi frekuensi dominan lapisan tanah di sekitar zona Sesar Lembang. Garis puth menunjukkan batas satuan litologi dan juga batas cekungan/situ. 


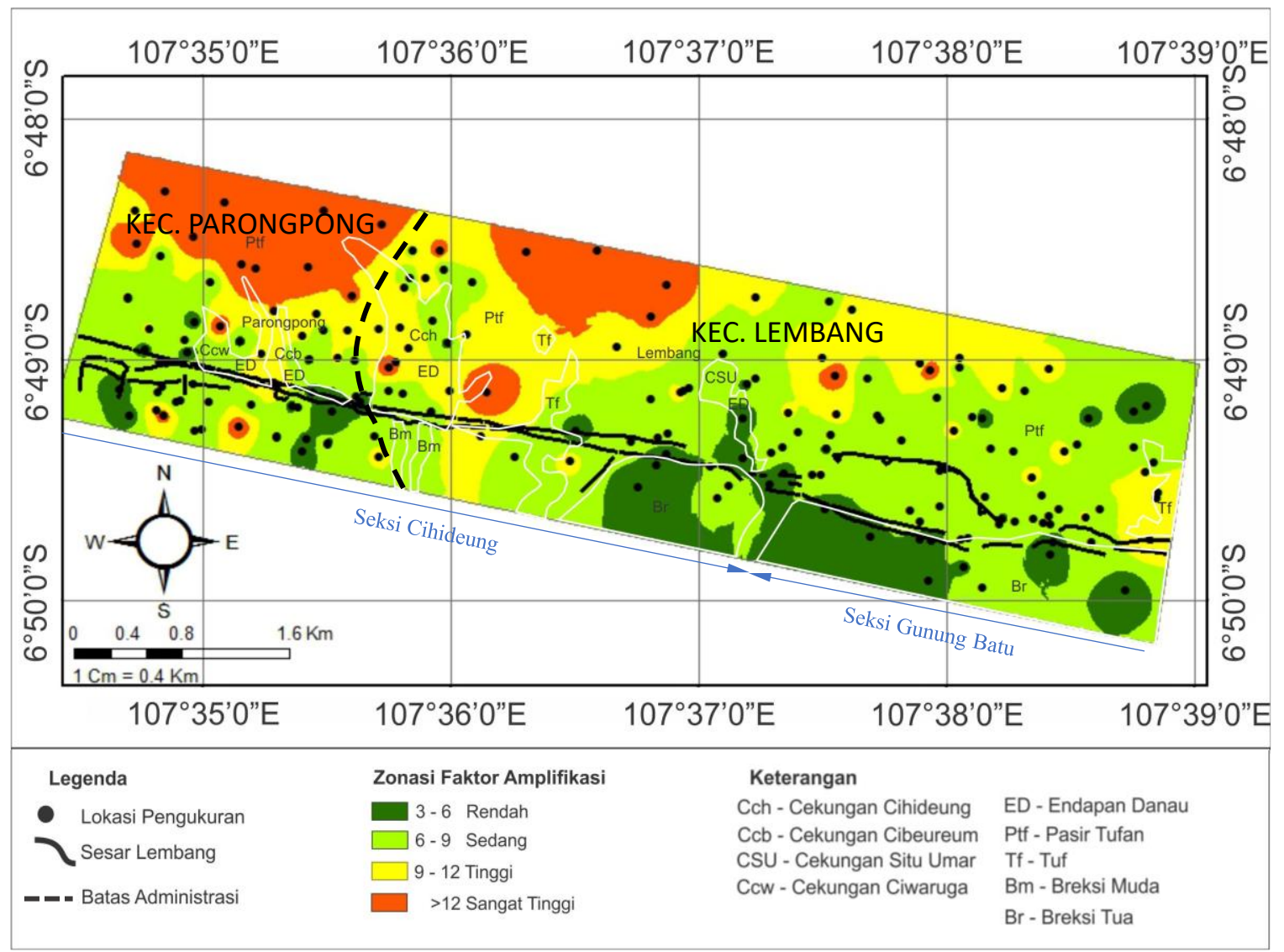

Gambar 6. Peta mikrozonasi nilai faktor amplifikasi di wilayah sekitar zona Sesar Lembang. Garis putih menunjukkan batas satuan litologi dan juga batas cekungan/situ.

mengindikasikan keberadaan suatu daerah cekungan purba yang semakin dalam ke arah utara dari Sesar Lembang pada Seksi Gunung Batu.

Berbeda dengan wilayah Kecamatan Lembang, lapisan pasir tufan dengan frekuensi dominan rendah di wilayah Kecamatan Parongpong umumnya berada di sisi utara dari Sesar Lembang Seksi Cihideung. Hal ini menunjukkan lapisan pasir tufan di wilayah ini relatif lebih tipis dibandingkan dengan lapisan pasir tufan di sisi selatan dari Seksi Cihideung dan di sisi utara dari Seksi Gunung Batu. Perbedaan ketebalan lapisan pasir tufan ini berasosiasi dengan kondisi topografi bawah permukaan akibat pergerakan Sesar Lembang yang mengontrol kedalaman lapisan batuan dasar di wilayah ini.

Nilai frekuensi dominan mulai dari 3 hingga $6 \mathrm{~Hz}$ tersebar di beberapa lokasi terutama di sebelah selatan dari Sesar Lembang di wilayah Kecamatan Lembang. Hal ini berasosiasi dengan faktor geologi di wilayah ini, yaitu keterdapatan lapisan breksi vulkanik yang terangkat ke permukaan akibat pergerakan normal dari Sesar Lembang. Dengan demikian, nilai frekuensi dominan di lokasi ini mengindikasikan ketebalan lapisan tanah penutup lapisan batuan breksi ini relatif lebih tipis dibandingkan dengan lapisan pasir tufan di sisi utara Seksi Cihideung dan Gunung Batu.

Berdasarkan hasil pengukuran mikrotremor di wilayah Kecamatan Parongpong yang terletak di sebelah utara dari Seksi Cihideung, lapisan pasir tufan di beberapa lokasi juga memiliki nilai frekuensi dominan antara 3 dan $6 \mathrm{~Hz}$. Hasil pengukuran ini menunjukkan keberadaan lapisan pasir tufan yang tidak tebal di wilayah ini. Atau dengan kata lain, terdapat lapisan batuan dasar pada kedalaman dangkal di wilayah ini. Selain itu, Gambar 5 juga memperlihatkan lapisan tanah di wilayah ini yang mempunyai nilai frekuensi dominan lebih besar dari $6 \mathrm{~Hz}$, terutama di daerah dekat alur sungai, mengindikasikan keberadaan lapisan batuan dasar yang berada sangat dekat permukaan tanah. 


\section{Sebaran nilai faktor amplifikasi}

Peta kontur nilai faktor amplifikasi yang diperoleh dari penentuan puncak amplitudo spektrum HVSR ditunjukkan pada Gambar 6. Nilai faktor amplifikasi menjelaskan adanya kontras impedansi antara lapisan tanah permukaan terhadap lapisan batuan dasar (Ansal, 2004), dengan kata lain faktor amplifikasi merupakan suatu parameter yang memberikan informasi mengenai struktur internal lapisan sedimen yang lunak (Saaduddin et al., 2015; Rusdin et al., 2016). Nilai faktor amplifikasi yang diperoleh bervariasi dengan nilai minimum sebesar 3 yang tersebar di 180 titik pengukuran. Daerah-daerah yang disusun oleh breksi vulkanik tua dan yang berada pada aliran sungai umumnya memiliki faktor amplifikasi yang rendah dengan nilai $A_{0}$ antara 3 dan 6. Sedangkan daerah yang tersusun oleh lapisan pasir tufan dan endapan danau mempunyai nilai faktor amplifikasi lebih dari 6 . Adapun nilai faktor amplifikasi untuk satuan litologi tuf dan breksi vulkanik muda diperoleh berdasarkan hasil interpolasi data-data lokasi terdekatnya.

Sebagaimana dapat dilihat pada Gambar 6, daerah-daerah yang tersusun oleh endapan danau umumnya memiliki nilai faktor amplifikasi lebih dari 9, mengindikasikan bahwa lapisan endapan danau ini mempunyai kepadatan yang rendah. Dengan demikian, daerah-daerah bekas situ/ danau yang saat ini sudah berubah menjadi pemukiman, seperti Situ Cihideung akan mengalami goncangan gempabumi yang kuat sebagai akibat dari efek cekungan (basin effect).

Berdasarkan Gambar 6, lapisan pasir tufan yang mendominasi di daerah penelitian memiliki nilai faktor amplifikasi yang bervariasi. Hasil analisis ini menunjukkan bawah lapisan pasir tufan mempunyai kepadatan yang bervariasi. Di wilayah Kecamatan Lembang, lapisan pasir tufan di wilayah Seksi Gunung Batu memiliki kepadatan yang lebih tinggi dibandingkan dengan lapisan pasir tufan di wilayah Seksi Cihideung. Sementara itu, kepadatan lapisan pasir tufan di wilayah Kecamatan Parongpong pada Seksi Cihideung semakin meningkat ke arah utara. Dengan demikian, wilayah sebelah utara dari sesar Lembang cenderung akan mengalami goncangan gempabumi yang lebih kuat dibandingkan wilayah di sisi selatan sesar.

Gambar 6 juga memperlihatkan daerah-daerah yang memiliki nilai faktor amplifikasi rendah, terutama di wilayah Kecamatan Lembang pada Seksi Gunung Batu. Faktor amplifikasi rendah ini berasosiasi dengan keberadaan lapisan breksi vulkanik keras yang muncul ke dekat permukaan tanah akibat pergerakan Sesar Lembang. Oleh karena itu, daerah-daerah yang tersusun oleh lapisan breksi vulkanik ini tidak akan mengalami goncangan yang kuat ketika terjadi gempabumi di wilayah ini.

\section{Sebaran nilai indeks kerentanan seismik}

Peta kontur nilai kerentanan seismik yang diperoleh berdasarkan persamaan Nakamura (1997) ditunjukkan pada Gambar 7. Daerah dengan kerentanan seismik rendah hingga sangat rendah dengan nilai $K_{g}<21$ umumnya tersebar di wilayah perbukitan matang berelief tinggi yang tersusun oleh lapisan batuan breksi vulkanik dengan lapisan tanah penutup yang sangat tipis di wilayah Kecamatan Lembang. Sementara itu, daerah kerentanan seismik sedang dengan nilai $K_{g}$ antara 21 dan 30 tersebar di beberapa lokasi penelitian baik di wilayah Kecamatan Lembang ataupun di wilayah Kecamatan Parongpong, terutama pada daerah-daerah yang tersusun oleh lapisan pasir tufan di kaki lereng perbukitan sepanjang zona Sesar Lembang pada Seksi Cihideung. Sedangkan daerah dengan nilai kerentanan seismik tinggi hingga sangat tinggi $\left(K_{g}\right.$ $>30$ ) didominasi oleh daerah yang tersusun atas lapisan endapan danau dengan topografi datar halus dan daerah yang tersusun atas lapisan pasir tufan dengan topografi bergelombang halus di wilayah Kecamatan Lembang dan Parongpong. Dengan demikian, daerah-daerah tersebut memiliki potensi bahaya goncangan gempabumi yang tinggi sehingga dapat memicu kerusakan bangunan yang rentan terhadap goncangan.

Hasil analisis sebaran indeks kerentanan seismik ini menunjukkan bahwa selain faktor litologi, kerentanan seismik di wilayah Sesar Lembang juga dikontrol oleh kondisi topografi. Indeks kerentanan seismik semakin menurun pada topografi perbukitan. Hasil beberapa penelitian terdahulu juga memperlihatkan hubungan yang jelas antara indeks kerentanan seismik dan bentuk lahan (Gurler et al., 2000; Nakamura, 2008; Daryono et al., 2018). 


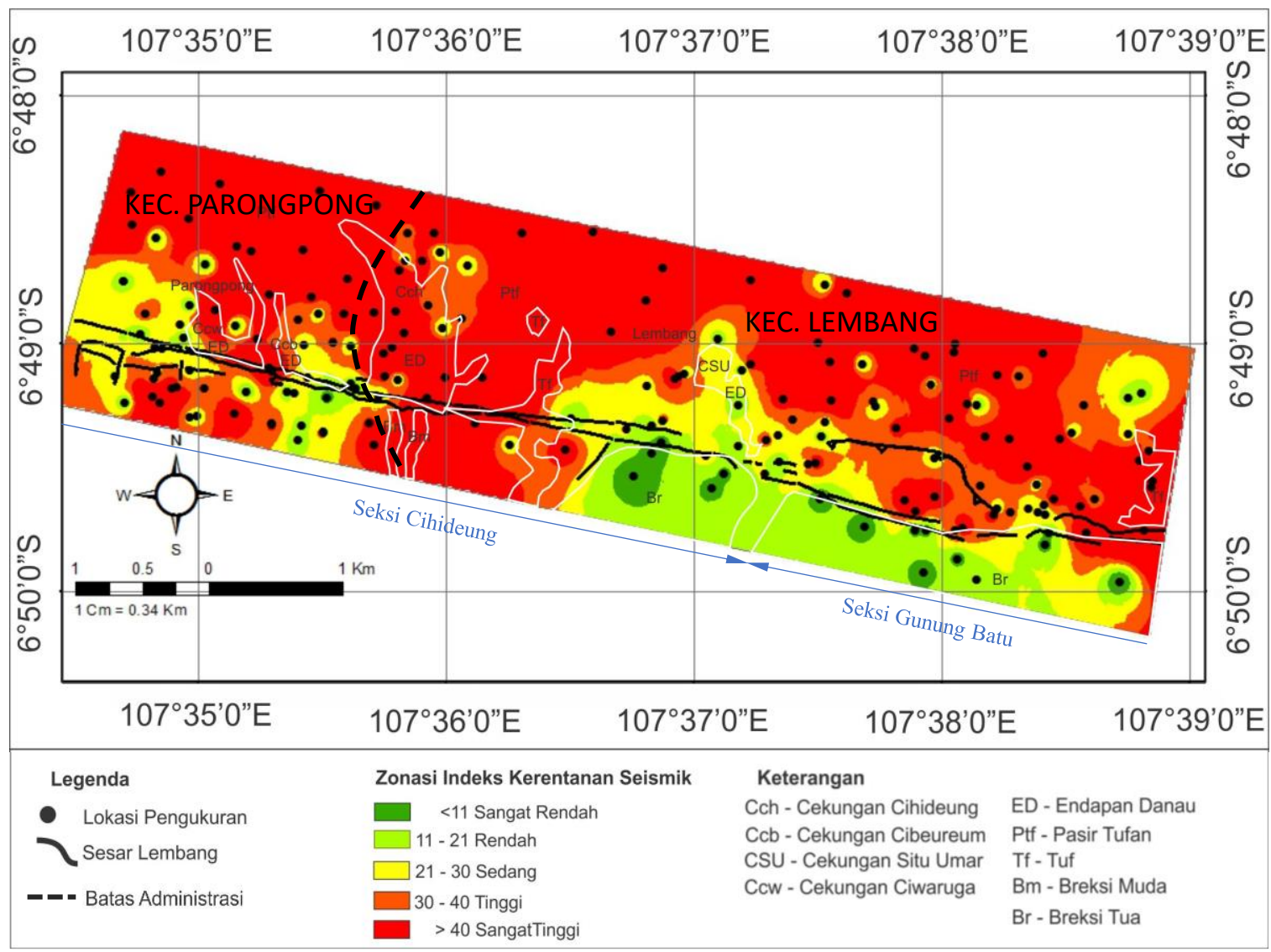

Gambar 7. Peta mikrozonasi nilai indeks kerentanan seismik di wilayah zona Sesar Lembang. Garis putih menunjukkan batas satuan litologi dan juga batas cekungan/situ.

\section{KESIMPULAN}

Berdasarkan hasil penelitian kerentanan seismik menggunakan pengukuran mikrotremor dengan metode HVSR (Horizontal to Vertical Spectral Ratio) pada zona Sesar Lembang antara Seksi Cihideung dan Gunung Batu di wilayah Kecamatan Lembang dan Parongpong, dapat disimpulkan bahwa:

(1) Berdasarkan nilai frekuensi dominan, wilayah yang berada pada zona Sesar Lembang diketahui memiliki nilai frekuensi dominan yang bervariasi akibat perbedaan jenis satuan litologi di setiap wilayah. Pada umumnya nilai frekuensi dominan tanah berkisar antara $0-3 \quad \mathrm{~Hz}$ karena didominasi oleh lapisan pasir tuf dan endapan danau.

(2) Daerah yang tersusun oleh breksi vulkanik tua yang terangkat oleh komponen sesar naik di wilayah Kecamatan Lembang ditandai dengan nilai frekuensi dominan antara 3 dan $6 \mathrm{~Hz}$.

(3) Berdasarkan nilai faktor amplifikasi, daerah yang memiliki nilai faktor amplifikasi sangat tinggi berada di wilayah Kecamatan Parongpong sisi sebelah utara zona Sesar Lembang dengan nilai $A_{0}$ lebih besar dari 12, hal ini mengindikasikan wilayah tersebut tersusun dari lapisan pasir tufan yang tebal dan tidak padat.

(4) Berdasarkan nilai kerentanan seismik, Kecamatan Lembang memiliki nilai kerentanan seismik sangat rendah di sisi sebelah selatan zona Sesar Lembang karena tersusun atas batuan breksi tua. Sedangkan daerah dengan indeks kerentanan seismik tinggi hingga sangat tinggi tersebar di wilayah Kecamatan Lembang dan Parongpong, termasuk daerah bekas danau/ situ sehingga daerah-daerah tersebut akan mengalami goncangan gempabumi yang kuat. 
(5) Hasil penelitian ini menunjukkan bahwa jenis litologi dan topografi lahan di wilayah Sesar Lembang mempunyai pengaruh yang kuat terhadap sebaran nilai sifat dinamika lapisan tanah dan kerentanan seismik di wilayah ini.

\section{Kontribusi masing-masing penulis}

RF mengumpulkan dan mengolah data mikrotremor, AT menganalisis data mikrotremor, dan IM membantu pengolahan data mikrotremor. Para penulis adalah sebagai kontributor utama dan memberikan kontribusi yang sama dalam penulisan makalah ini.

\section{UCAPAN TERIMA KASIH}

Penulis mengucapkan terima kasih kepada Kepala Pusat Penelitian Geoteknologi LIPI yang telah memberikan dukungan peralatan mikrotremor kepada penulis untuk melakukan penelitian ini.

\section{DAFTAR PUSTAKA}

Abidin, H. Z., Andreas, H., Kato, T., Ito, T., Meilano, I., Kimata, F., Natawidjaya, D. H., Harjono, H., 2009. Crustal deformation studies in Java (Indonesia) using GPS. Journal of Earthquake and Tsunami, 3(02), 77-88.

Ansal, A., 2004. Recent Advances in Earthquake Geotechnical Engineering and Microzonation. Kluwer Academic Publishers, Dordrecht, 354 pp.

Bonnefoy-Claudet, S., Leyton, F., Baize, S., Berge-Thierry, C., Bonilla, L. F., Campos, J., 2008. Potentiality of microtremor to evaluate site effects at shallow depths in the deep basin of Santiago De Chile. Proc. 14th WCEE Beijing, China, http://www.iitk.ac .in/nicee/wcee/fourteenth_conf.china.

BPS Propinsi Jawa Barat, 2019. Propinsi Jawa Barat dalam angka tahun 2019. Badan Pusat Statsitik Propinsi Jawa Barat, ITB Press, Bandung, 497 halaman.

Brahmantyo, B., 2011. Sesar Lembang, hearthquake di jantung Cekungan Bandung. Geo Magz, 1(1), 17-25.

Claprood, M., Asten, M. W., 2008. Microtremor survey methods in the Tamar Valley,
Launceston, Tasmania: evidence of 2D resonance from microtremor observations. Proc. Earthquake Engineering in Australia Conference, AEES, Ballarat, November 2008, Paper 20.

Dam, M. A. C., 1994. The Late Quaternary Evolution of the Bandung Basin, West Java, Indonesia $[\mathrm{PhD}$ : Vrije Universitet].

Dam, M. A. C., Suparan, P., Nossin, J. J., Voskuil, R. P. G. A., 1996. A chronology for geomorphological developments in the greater Bandung, Indonesia. Journal of SE Asian Earth Science, 12 (1/2), 101115.

Daryono, Brotopuspito, K. S., Sutikno, 2018. Hubungan antara indeks kerentanan seismik dan rasio kerusakan pada satuan bentuklahan di zona graben Bantul. Prosiding Seminar Nasional Kebumian ke 11, Yogyakarta, 1140-1151.

Daryono, M. R., 2016. Paleoseismologi Tropis Indonesia (Dengan Studi Kasus di Sesar Sumatra, Sesar Palu-Koro, Sesar Matano dan Sesar Lembang). Disertasi Program Doktor, Institut Teknologi Bandung, Tidak dipublikasikan.

Daryono, M. R, Natawidjaja, D. H., Sapiie, B., Cummins, P., 2019. Earthquake geology of the Lembang Fault, West Java, Indonesia. Tectonophysics, 751, 180191.

Davenport, P. N., Stephenson, W. R., 2005. Use of microtremors to assess local site effects. Proceedings of New Zealand Society for Earthquake Engineering Conference, Wairakei Resort, Taupo, New Zealand, 9, 11-13.

Eskisar, T., Őzyalin, S., Kuruoğlu, M., Yilmaz, H. R., 2013. Microtremor measurements in the Northern Coast of Izmir Bay, Turkey to evaluate site-specific characteristics and fundamental periods by $\mathrm{H} / \mathrm{V}$ spectral ratio method. Journal of Earth System Science, 122(1), 123-136.

Fallahi, A., Alaghebandian, R. Miyajima, M., 2003. Microtremor measurements and building damage during the Changureh- 
Avaj, Iran Earthquake of June 2002. Journal of Natural Disaster Science, 25(1), 37-46.

Gosar, A. J., 2009. A microtremor HVSR study of the seismik site effects in the area of the town of Brezice (SE Slovenia). Acta Geotechnica Slovenica, 2, 31-45.

Gurler, E. D., Nakamura, Y., Saita, J., Sato, T., 2000. Local site effect of Mexico City based on microtremor measurement. Proceeding of the $6^{\text {th }}$ International Conference on Seismik Zonation, California, USA, 65-77.

Harijono, S. W. B., 2010. InaTEWS, Indonesia tsunami early warning system: konsep dan implementasi. Badan Meteorologi Klimatologi dan Geofisika (BMKG) Indonesia.

Kartadinata, M. N., Okuno, M., Nakamura, T., Tetsuo, K., 2002. Eruptive history of Tangkuban Perahu Volcano, West Java, Indonesia: a preliminary report. Journal of Geography, 111, 404-409.

Kertapati, E. K., 2006. Aktivitas Gempabumi di Indonesia: Perspektif Regional Pada Karakteristik Gempabumi Merusak. Bandung: Departemen Energi dan Sumber Daya Mineral, 109 halaman.

Kiyono, J., Ono, Y., Sato, A., Noguchi, T., Putra, R. R., 2011. Estimation of subsurface structure based on microtremor observations at Padang, Indonesia. ASEAN Engineering Journal, Part C, 1 (3), 66-81.

Marjiyono, Soehaimi, A., Kamawan, 2008. Identifikasi sesar aktif daerah Cekungan Bandung dengan data citra landsat dan kegempaan. Jurnal Geologi dan Sumberdaya Mineral, 18(2), 81-88.

Nakamura, Y., 1989. A Method for dynamic characteristic estimation of subsurface using microtremor on the ground surface. Quarterly Report, Railway Technical Research Institute, 30, 25-33.

Nakamura, Y., 1997. Seismic vulnerability Indices for ground and structures using microtremor, World Congress on Railway Research, Florence, Italy.

Nakamura, Y., 2000. Clear identification of fundamental idea of Nakamura's technique and its applications. In: Proceedings of the 12th world conference on earthquake engineering (WCEE), Auckland. http://www.nicee.org/wcee/

Nakamura, Y., 2008. On the H/V spectrum. In: Proceedings of the 14th world conference on earthquake engineering (WCEE), Beijing. http://www.nicee.org/wcee/

Rusdin, A. A., Hadmoko, D. S., Sunarto, Saaduddin, 2016. Analisis pengaruh karakteristik sedimen dan kedalaman muka airtanah terhadap indeks kerentanan seismik Kota Makassar. Prosiding Seminar Nasional Geofisika 2016, Makassar.

Saaduddin, Sismanto, Marjiyono, 2015. Pemetaan indeks kerentanan seismik Kota Padang dan korelasinya dengan titik kerusakan gempabumi 30 September 2009. Prosiding Seminar Nasional Kebumian ke-8, Universitas Gajah Mada, Yogyakarta, 459-466.

Silitonga, P. H., 1973. Peta Geologi Lembar Bandung, Jawa, Skala 1: 100.000. Direktorat Geologi, Bandung.

Tjia, H. D., 1968. The Lembang Fault, West Java. Geologie En Mijnbouw 47 (2), 126-130.

Tohari, A., Wardhana, D. D., 2018. Mikrozonasi seismik wilayah Kota Padang berdasarkan pengukuran mikrotremor. Jurnal RISET Geologi dan Pertambangan, 28(2), 205-220.

Tuladhar, R., Yamazaki, F., Warnitchai, P., Saita, J., 2004. Seismik microzonation of the greater Bangkok area using microtremor observations. Earthquake Engineering and Structural Dynamic, 33, 211-225 DOI: 10.1002/eqe.345

Van Bemmelen, R., 1949. The Geology of Indonesia. Government Printing Office, The Hague, Netherlands, 732 p. 